Zoologica Poloniae (2011) 56/1-4: 35-48

DOI: $10.2478 / \mathrm{v} 10049-011-0006-6$

\title{
REGULARITIES OF VARIATION OF THE RED BLOOD INDICES CHARACTERIZING THE RESPIRATORY FUNCTION OF BLOOD IN SELECTED FISH
}

\author{
Sebastian Maciak* and Alina Kostelecka-Myrcha
}

Institute of Biology, University of Białystok, Świerkowa 20B, 15-950 Białystok, Poland, e-mail: maciaks@uwb.edu.pl

* Corresponding author

\begin{abstract}
There is a large diversity of red blood indices determining oxygen transport ability in vertebrates. In fish this diversity is particularly large, probably due to the great variability in water environments, which impedes the possibility of finding and understanding general patterns. It has been assumed that in mammals, the measure determining the ability of a blood unit to transport oxygen is the ratio of hemoglobin concentration (HB) and total erythrocyte surface area (TSAE). It was also shown that both in mammals and birds the amount of hemoglobin per total surface area unit $(\mathrm{Hb} /$ TSAE) conditions maximum use of respiratory pigment in oxygen transport, in different physiological and environmental conditions. In order to check whether this regularity occurs in fish, red blood indices were analyzed in seven species of freshwater fish, differing noticeably in their biology and body mass in two seasons of the year. Notwithstanding this marked seasonal variability to the component variables together determining the total surface area of erythrocytes, the value for TSAE was found to differ in proportion to the higher or lower concentrations of HB. In consequence, the $\mathrm{HB} / \mathrm{TSAE}$ ratio indicative of the maximal use of haemoglobin in the transport of oxygen was constant in all of the fish studied between analyzed seasons. This constancy resembling that to be noted in birds - is most probably related to the counter-current gaseous exchange ongoing in the gills of fish.
\end{abstract}

Key words: blood, oxygen capacity, haematological parameters, seasonality, fish 


\section{INTRODUCTION}

Values for red blood indices reflect the evolutionary adaptation of animals to life in defined environmental conditions as well as the physiological state of the particular individual (SNyder and Sheford 1999, Gregory 2001, Homatowska et al. 2002, Hardie and HeBert 2003). Linear parameters describing the sizes of erythrocytes offer an important depiction of maximal saturability of haemoglobin (HB) with oxygen, and hence of the efficiency with which the gas is transported to the tissues (Nikinmaa and Salama 1998, Cooper et al. 2001, Maciak et al. 2011). The results of earlier haematological studies on mammals and birds have shown that the capacity of haemoglobin to become maximally oxygen-saturated is dependent on the ratio between the HB concentration and the total surface area of erythrocytes (TSAE), the latter being derived from both the sizes (S) and numbers of cells of this type (RBC) (Kostelecka-Myrcha 1997, 2002, KosteleckaMyrcha and Cholostiakow-Gromer 2001). Differences in these parameters that may be present among different fish species can be regarded as playing an important role where the shaping of the blood's capacity to transport oxygen (and hence the metabolic efficiency of the organism) is concerned. The ongoing lack of information on normal ranges of these values for haematological parameters characterising different fish species frequently results in an inability to understand or correctly interpret their physiological mechanisms (LuSKoví 1997, NikinmaA 2002). While it is known that a significant influence on values of the aforementioned indices is exerted by a number of different external factors (Filho et al. 1992, Lusková 1997, Ytrestøyl et al. 2001, Nespolo and RosenmanN 2002, Nikinmaa 2002), these have frequently proved hard to define precisely in artificial laboratory or farm conditions. A good example here might be seasonality of climate as manifested in temperature change and oxygenation of water, among other things, these undoubtedly influence values for haematological parameters in fish (WIESER 1991, LUSKOVÁ 1997, 1998). Likewise, in spite of the now well-documented influence of the external environment on blood morphology, the directions to seasonal changes in values for the haematological parameters in the animal group in question have remained unclear (GUIJARro et al. 2003).

In earlier hematological studies, it has been shown that the $\mathrm{Hb} / \mathrm{TSAE}$ ratio in mammals is shown to depend on species' body masses - most probably in reflection of the essential need for small animals with their high basal metabolic rates to maintain more efficient oxygen transport (KosteleCKA-MyrCha 1973, 2002, Promislow 1991). Undoubtedly playing a great role in this case is the much more rapid capillary transit that greatly reduces the time needed for gaseous exchange to take place in the lungs of small mammals. It is thus through the distribution of the same amount of haemoglobin per unit volume of blood as occurs in large mammals across a greater total surface area (TSAE) that small mammals are capable of making equally effective use of the respiratory protein (Kostelecka-Myrcha 2002). It likewise emerges that the Hb/TSAE ratio is constant in birds, irrespective of body masses, season of the year, or the age 
of individual specimens (Kostelecka-Myrcha 1997, Kostelecka-Myrcha and Choøostiakow-Gromek 2001). This constancy suggests that the oxygen-saturation of haemoglobin in birds takes place under constant conditions ensuring counter-current gaseous exchange in the tubular lungs of these animals, the contact between erythrocytes and oxygen being dependent on time, of which there is always a relatively large amount.

Of evident interest in the light of this would be the shaping of the $\mathrm{Hb}$ / TSAE ratio in a vertebrate class differing from the above in being endothermic and not hitherto researched in this regard. A high degree of sensitivity to environmental conditions reflecting the endothermy of fish, as accompanied by major variations in values for their haematological indices, attest to considerable adaptability where the respiratory function of blood in these animals is concerned. In consequence, study of this property among fish through the different seasons of the year was predicted to help shed light on the efficiency of the mechanism by which fish tissues are supplied with oxygen; while comparative research on haematological indices in fish seemed likely to allow for the identification of trends to seasonal changes in the component parameters, as well as an augmentation of the still-sparse data in litt. regarding typical fish species of Central Europe. Thus the aim of the present study was to check for regularities in fish red blood cell indices in terms of their respiratory function as well as direction of potential changes of them in two different seasons of the year.

\section{MATERIALS AND METHODS}

The species studied in respect of their haematological parameters were freshwater wild-living fish i.e. the crucian carp (Carassius carassius), common bream (Abramis brama), carp (Cyprinus carpio), grass carp (Ctenopharyngodon idella), and northern pike (Esox lucius), or farmed species i.e. rainbow trout (Oncorhynchus mykiss), and atlantic sturgeon (Acipenser oxyrinchus) all existing in Central Europe and in some sense "characteristic" thereof. Body masses in the studied individuals of these species ranged from $0.43 \mathrm{~kg}$ through to $2.56 \mathrm{~kg}$. The captures of fish and their sampling for the purposes of analysis took place in two seasons of the year, i.e. spring (May-June) and autumn (October-November), in the years 2008-2009. Animals were physically stunned and then dissected, with the blood for analysis being collected directly from the conus arteriosis. The principle measurements (of haematocrit and numbers of erythrocytes per $\mathrm{mm}^{3}$ of blood) were made immediately at the place of capture, while remaining parameters were studied once the material had been transferred to the laboratory.

The number of erythrocytes $\left(\mathrm{RBC} \mathrm{mln} / \mathrm{mm}^{3}\right.$ ) was determined by counting in a Bürker Chamber, after prior dilution of blood with Hayem's solution. Haematocrit (HCT \%) was studied using micromethods involving centrifugation in heparinised capillaries. The concentration of haemoglobin (HB g\%, i.e. grams of HB per 100 cubic centimetres of blood) was determined using the cyanomethaemoglobin method (WINTRoBe 1967) on a Shiemadzu UV-1201 V spectrophotometer at a wavelength of $540 \mathrm{~nm}$. The mean corpuscular haemoglobin 
concentration $(\mathrm{MCHC} \%)$ and mean corpuscular volume $\left(\mathrm{MCV} \mathrm{mm} \mathrm{mm}^{3}\right)$, were calculated from the number of erythrocytes per $\mathrm{mm}^{3}$ of blood, the haematocrit, and the haemoglobin concentration, using standard formulas (Wintrobe 1967). In order to measure lengths and widths of erythrocytes (respectively LC and WC $\mathrm{mm}$ ), as well as of their nuclei (LN and WN mm), smears of blood were prepared for staining using Pappenheim's method. The measurements, with the image under the microscope being sent by video camera to a computer, were made for 50 randomly-selected cells from each individual, using the MultiScan Base for Windows v.14.02 (CSS Ltd. Warsaw, Poland).

As differences in the sizes of erythrocytes in fish are associated with differences in cell shape (see Results), it was necessary for calculations of the surface area of red blood cells (S) to make use of a formula for the surface area of a triaxial ellipsoid. The simultaneous accounting for the three cell dimensions of length, width and thickness using this formula was found to give a good description of differences in the surface areas of cells in line with their different shapes. The total surface area of erythrocytes (TSAE) was calculated as the product of the number of erythrocytes in one $\mathrm{mm}^{3}$ of blood and the surface area of a single erythrocyte, where $T S A E=R B C^{\star} S$ (see Appendix 1) (KosteleckAMyrcha 1997).

The normality of distributions was tested using the Shapiro-Wilk $W$ test. Differences between mean values for erythrocyte indices in all of the studied animals were tested using two-factor analysis of covariance (ANCOVA), with body mass as covariate. Differences between mean values for different haematological parameters in the two seasons were in turn analysed using the Student t-test. The significance of the dependent relationships between pairs of selected parameters was tested using regression analysis. In each test, $\mathrm{p}<0.05$ was the accepted probability level taken to indicate statistical significance. Standard deviations to the mean values were calculated.

\section{RESULTS}

Analysis of variance of the relationship between length-to-breadth and length-to-thickness ratios ( $\mathrm{LC} / \mathrm{TC}$ and $\mathrm{WC} / \mathrm{TC})$ in the different seasons were found to differ significantly in the species studied (ANOVA; $<<0.05$ ). In the remaining values for all parameters analyzed, these differences were still more marked where analysis concerned values for the two seasons combined. Thus, for the LC/TC ratio, ANOVA F=16.56; $\mathrm{p}<0.0001$, and for the $\mathrm{WC} / \mathrm{TC}$ ratio, ANOVA $\mathrm{F}=10.06 ; \mathrm{p}<0.0001$. The fact that the ratios for both length and width to thickness differed in different species suggests that a change in erythrocyte size in fish is associated with a change in RBC shape. This in turn makes it necessary for account to taken of the third cell dimension of thickness if correct calculations of surface area are to be made.

Data for all parameters analyzed were distributed normally. Body size was not a significant covariate in any case. 
The values for the different haematological parameters in the species studied over the two seasons are given in the Tables. The species differed significantly in terms of the numbers of erythrocytes per $\mathrm{mm}^{3}$ of blood in both spring and autumn (ANCOVA, $\mathrm{p}<0.0001)$ (Table 1). Differences in numbers of red blood cells were always inversely correlated with differences in their linear dimensions (both length and width) and hence differences in volume.

The studies carried out in spring and autumn gave a clear indication of the degree to which variability in values for erythrocyte indicators in the different species was likely to be seasonal. Compared with spring captures, fish obtained in autumn are characterized by significantly greater numbers of erythrocytes, and significantly greater amounts of haemoglobin, in their blood (Student t-test, $\mathrm{p}<0.01$ for all cases). Erythrocyte length is also significantly greater in autumncaught fish (Student t-test, $\mathrm{p}<0.05$ for all cases). In contrast, red blood cells were less wide (albeit with statistical significance not achieved in the cases of bream and crucian carp) and less thick (Student t-test, $\mathrm{p}<0.01$ ). These smaller sized erythrocytes, in terms of width and thickness as well as volume, allow greater numbers of red blood cells to be present, the result being a total surface area that is significantly greater $(\mathrm{p}<0.05$ in all species), notwithstanding the fact that both haematocrit and $\mathrm{MCHC}$ values remained relatively similar in both seasons. As the different concentrations of haemoglobin remained proportionate to the total surface area of erythrocytes (Fig. 1), the value for the HB/TSAE

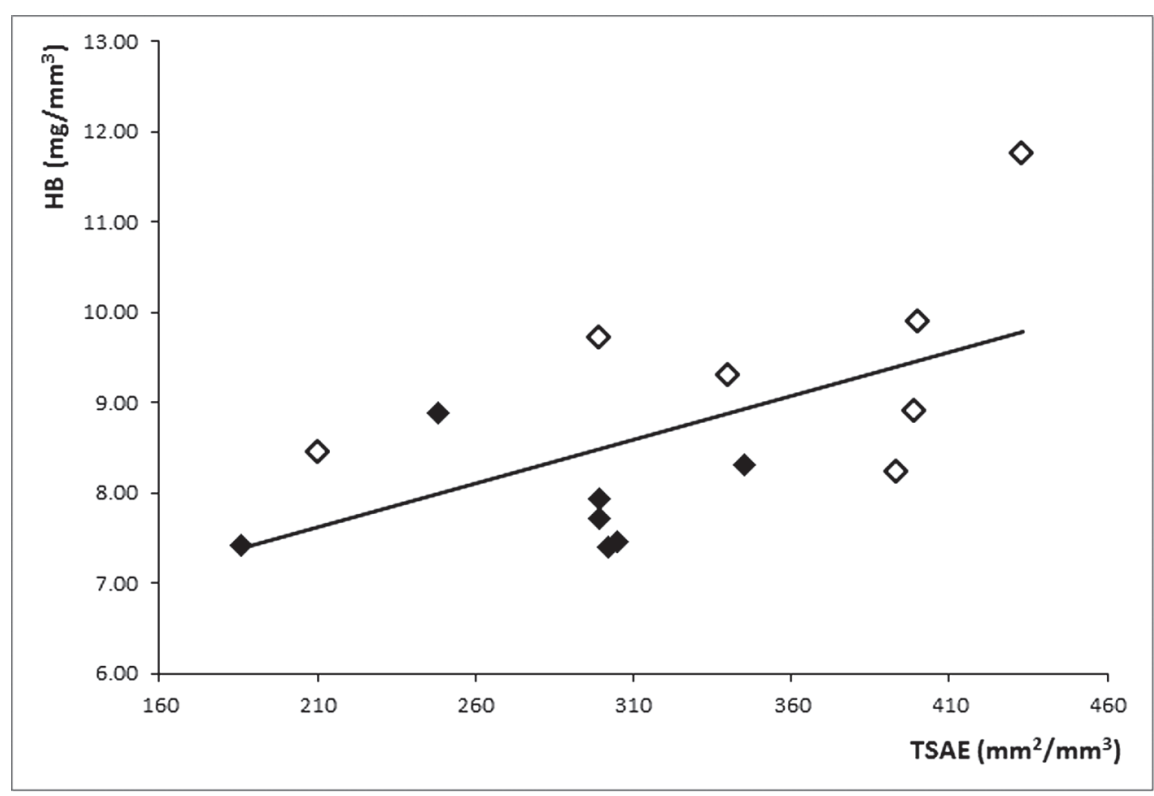

Fig. 1. The relationship between the representative measure of the total surface are of erythrocytes (TSAE) and the concentration of HB in selected species of freshwater fishes in spring (dark figures) and autumn (open figures). Solid line represents OLS regression for all data $(\mathrm{HB}=0.97 \mathrm{TSAE}+557.62, \mathrm{r}=0.58 ; \mathrm{p}<0.0001)$ 
Table 1. Comparison of several hematological parameters \pm SD in two seasons (spring: May-June, autumn: October-November) for five species of freshwater fishes. BM - body mass $(\mathrm{kg})$, RBC - number of red blood cells $\left(\mathrm{mln} / \mathrm{mm}^{3}\right), \mathrm{HB}-\mathrm{hemog} l o b i n$ concentration $(\mathrm{g} \%)$, TSAE - total surface area of erythrocytes $\left(\mathrm{mm}^{2} / \mathrm{mm}^{3}\right)$, HB/TSAE - haemoglobin to total surface area of erythrocytes ratio $\left(\mathrm{pg} / \mathrm{mm}^{3}\right)$. abcde - significant differences between each species in one season as adjusted mean from ANCOVA; *significant differences between each hematological parameter in two seasons analyzed with t-test.

\begin{tabular}{|c|c|c|c|c|c|c|c|c|}
\hline \multirow{2}{*}{ Species } & \multicolumn{4}{|c|}{ Spring } & \multicolumn{4}{|c|}{ Autumn } \\
\hline & $\mathrm{RBC}$ & $\mathrm{HB}$ & TSAE & $\mathrm{Hb} / \mathrm{TSAE}$ & $\mathrm{RBC}$ & $\mathrm{HB}$ & TSAE & $\mathrm{Hb} / \mathrm{TSAE}$ \\
\hline Esox lucius ${ }^{\mathrm{a}}$ & $1.45 \pm 0.3^{\mathrm{de}}$ & $7.46 \pm 1.77$ & $305 \pm 64.58^{\mathrm{fg}}$ & $0.025 \pm 0.004^{\mathrm{fg}}$ & $1.86 \pm 0.3^{\mathrm{dg} *}$ & $8.24 \pm 1.87^{\mathrm{ce}}$ & $393 \pm 61.99^{\mathrm{fg}} *$ & $0.021 \pm 0.004^{\mathrm{fg}} *$ \\
\hline 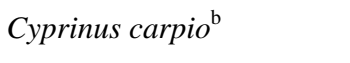 & $1.21 \pm 0.19^{\mathrm{a}}$ & $7.94 \pm 1.16$ & $299 \pm 45.31^{\mathrm{efg}}$ & $0.027 \pm 0.004^{\mathrm{fg}}$ & $1.5 \pm 0.33^{\mathrm{fg} *}$ & $9.31 \pm 1.16^{\mathrm{e}_{*}}$ & $340 \pm 60.97^{\mathrm{fg}_{*}}$ & $0.027 \pm 0.00^{\mathrm{fg}}$ \\
\hline Abramis brama ${ }^{\mathrm{c}}$ & $1.35 \pm 0.31^{\mathrm{e}}$ & $7.39 \pm 1.35$ & $302 \pm 57.92^{\mathrm{fg}}$ & $0.025 \pm 0.004^{\mathrm{fg}}$ & $1.73 \pm 0.28^{\mathrm{fg}_{*}}$ & $9.9 \pm 1.32^{\mathrm{e}} *$ & $400 \pm 52.12^{\mathrm{fg}_{*}}$ & $0.025 \pm 0.003^{\mathrm{afg}}$ \\
\hline Carassius carassius $^{\mathrm{d}}$ & $0.96 \pm 0.1^{\mathrm{bc}}$ & $7.72 \pm 1.41$ & $299 \pm 52.09^{\mathrm{fg}}$ & $0.026 \pm 0.005^{\mathrm{fg}}$ & $1.37 \pm 0.6^{\mathrm{cg} *}$ & $8.9 \pm 1.64^{\mathrm{e}} *$ & $399 \pm 130.05^{\mathrm{fg}} *$ & $0.024 \pm 0.001^{\mathrm{fg}}$ \\
\hline Ctenopharyngodon idella ${ }^{\mathrm{e}}$ & $1.90 \pm 0.34^{\mathrm{bcd}}$ & $8.31 \pm 1.86$ & $345 \pm 64.6^{\mathrm{cdfg}}$ & $0.024 \pm 0.004^{\mathrm{fg}}$ & $2.28 \pm 0.29^{\mathrm{dfg}_{*}}$ & $11.75 \pm 1.44 *$ & $443 \pm 48.15^{\mathrm{fg}_{*}}$ & $0.026 \pm 0.002^{\mathrm{fg}}$ \\
\hline Oncorhynchus mykiss ${ }^{\mathrm{f}}$ & $0.7 \pm 0.17^{\text {abce }}$ & $8.89 \pm 1.44$ & $248 \pm 39.22^{\mathrm{g}}$ & $0.034 \pm 0.01^{\mathrm{g}}$ & $1.04 \pm 0.15^{\mathrm{g} *}$ & $9.71 \pm 1.35^{\mathrm{eg} *}$ & $299 \pm 41.38^{\mathrm{g}_{*}}$ & $0.033 \pm 0.04^{\mathrm{g}}$ \\
\hline Acipenser oxyrinchus ${ }^{\mathrm{g}}$ & $0.53 \pm 0.11^{\mathrm{abc}}$ & $7.41 \pm 1.6$ & $186 \pm 37.81$ & $0.038 \pm 0.00$ & $0.67 \pm 0.13^{*}$ & $8.45 \pm 1.39^{\mathrm{e}} *$ & $210 \pm 31.3 *$ & $0.04 \pm 0.005$ \\
\hline
\end{tabular}

Note: Differences in variance of mean HB/TSAE ratio between species are not statistically significant both for spring (ANCOVA $\mathrm{F}=1.30 ; \mathrm{p}=0.28$ ) and autumn (ANCOVA $\mathrm{F}=2.44 ; \mathrm{p}=0.1$ ), except rainbow trout and atlantic sturgeon. 
ratio was constant in the different species between analyzed seasons in all fish species, and interestingly remain constant irrespectively of the season of the year in five of them $(\mathrm{p}<0.05$, see Table 1$)$.

\section{DISCUSSION}

Fish are known as the vertebrates manifesting the greatest variation in values for haematological parameters (GREGORY 2001, HoMAtowsKa et al. 2002, HARDie and HeBert 2003, MACiAK et al. 2011). In the selected freshwater species studied here, the mean numbers of erythrocytes per $\mathrm{mm}^{3}$ of blood were found to vary across a twofold (Table 1). There was also considerable variability in erythrocyte size, reflecting differences in both linear parameters and volume (Tables 1,2). Confirmation is thus offered for a thesis expounded widely in the literature as regards interspecific differences in both sizes and numbers of red blood cells in fish (Lay and Baldwin 1999, Gregory 2001, Homatowska et al. 2002, Hardie and Hebert 2003, 2004, Maciak et al. 2011).

The data for the two different seasons support the contention that values for erythrocyte indices are subject to seasonal change (Table 1), the inferred variability apparently operating in the same way in all species studied. Thus autumn is associated with significantly greater numbers of erythrocytes and concentrations of haemoglobin in the blood of fish. The greater numbers of red blood cells are associated with significantly smaller erythrocyte volumes, first and foremost as a reflection of lesser thickness, and only to a more limited degree of lesser width, while lengths are actually greater. Thus an analysis of the cells' three dimensions is essential in the case of fish. The foregoing differences, assumed to reflect seasonal change, generate a significantly greater total surface area of erythrocytes while simultaneously maintaining a relatively constant value for both HCT and MCHC over the two seasons. Seasonal changes in haematological indices of the kind implicated were also invoked by HërdIG and Höglund (1984), Riera et al. (1993), LuSKová (1997, 1998), and Gujarro et al. (2003). However, those findings are often conflicting as regards directions to the changes in different species (see e.g. GuiJARro et al. 2003). In contrast, the present work reveals seasonal differences of the same nature in all species considered. The higher (increased) Hb concentration in autumn is most probably conditioned by declining amounts of dissolved oxygen in water, itself a result of higher summer temperatures (Wieser 1991, NikinMAa 2002, GUIJARro et al. 2003). This is the oldest-known evolutionary mechanism by which the circulatory system responds to hypoxia (NIKINMAa 2002), and the differences it achieves give rise to a proportionally greater total surface area of erythrocytes (TSAE), this in turn being interpretable as an "appropriate" response in terms of the surface area available for gaseous exchange.

Despite significant differences in HB values between various seasons, hemoglobin concentration did not differ statistically in species caught in spring and was minimally different in animals tested in autumn (Table 1). However the fluctuations of HB concentration in various seasons was also observed by e.g. 
Table 2. Comparison of erythrocytes size and concentration of hemoglobin between two seasons for five species of freshwater fishes. LC - cell length $(\mathrm{mm})$. WC - cell width $(\mathrm{mm})$. TC - cell thickness $(\mathrm{mm})$. MCV - mean cell volume $\left(\mathrm{mm}^{3}\right)$. MCHC - mean cell hemoglobin concentration (\%). abcde - significant differences between each species in one season as adjusted mean from ANCOVA; *significant differences between each hematological parameter in two seasons analyzed with t-test.

\begin{tabular}{|c|c|c|c|c|c|c|c|c|c|c|}
\hline \multirow{2}{*}{ Species } & \multicolumn{5}{|c|}{ Spring } & \multicolumn{5}{|c|}{ Autumn } \\
\hline & $\mathrm{LC}$ & $\mathrm{WC}$ & $\mathrm{TC}$ & $\mathrm{MCV}$ & $\mathrm{MCHC}$ & $\mathrm{LC}$ & $\mathrm{WC}$ & $\mathrm{TC}$ & $\mathrm{MCV}$ & $\mathrm{MCHC}$ \\
\hline Esox lucius ${ }^{\mathrm{a}}$ & $12.3 \pm 0.72^{\mathrm{de}}$ & $8.1 \pm 0.44^{\mathrm{de}}$ & $4.6 \pm 0.97^{\mathrm{f}}$ & $239 \pm 55.61^{\mathrm{de}}$ & $22.6 \pm 4.62^{\mathrm{g}}$ & $12.8 \pm 0.57^{\mathrm{d} *}$ & $8.5 \pm 0.3 *$ & $3.5 \pm 0.79^{\mathrm{f}_{*}}$ & $199 \pm 42.68^{\mathrm{df}_{*}}$ & $23.0 \pm 5.79$ \\
\hline Cyprinus carpio $^{\mathrm{b}}$ & $12.4 \pm 0.44^{\mathrm{de}}$ & $9.7 \pm 0.31^{\text {ae }}$ & $4.7 \pm 0.83^{\mathrm{f}}$ & $297 \pm 52.80^{\text {ae }}$ & $22.7 \pm 3.36^{\mathrm{g}}$ & $12.9 \pm 0.53^{\mathrm{d} *}$ & $9.3 \pm 0.5^{\mathrm{e}} *$ & $3.6 \pm 0.68^{\mathrm{f}} *$ & $228 \pm 48.65^{\mathrm{def}_{*}}$ & $23.0 \pm 2.66^{\mathrm{e}}$ \\
\hline Abramis brama $^{\mathrm{c}}$ & $11.9 \pm 0.71^{\mathrm{fg}}$ & $9.2 \pm 0.36^{\mathrm{ab}}$ & $4.6 \pm 0.95^{\mathrm{f}}$ & $265 \pm 54.44$ & $24.4 \pm 2.64^{\mathrm{g}}$ & $13.3 \pm 0.61^{\mathrm{a} *}$ & $8.9 \pm 0.93$ & $3.9 \pm 0.66^{\mathrm{f}} *$ & $241 \pm 33.26^{\mathrm{aef}}$ & $24.0 \pm 2.21$ \\
\hline Carassius carassius $^{\mathrm{d}}$ & $14.6 \pm 1.25^{\mathrm{ce}}$ & $10.3 \pm 0.71^{\mathrm{bc}}$ & $5.2 \pm 0.81^{\mathrm{a}}$ & $411 \pm 68.84^{\mathrm{bc}}$ & $25.9 \pm 3.20^{\mathrm{bg}}$ & $16.2 \pm 1.19^{\mathrm{c}_{*}}$ & $9.9 \pm 0.63^{\mathrm{ac}}$ & $3.7 \pm 1.22^{\mathrm{f}_{*}}$ & $311 \pm 97.22^{\text {cef } *}$ & $23.2 \pm 2.54^{\mathrm{eg}}$ \\
\hline Ctenopharyngodon idella ${ }^{\mathrm{e}}$ & $11.1 \pm 0.41^{\mathrm{cfg}}$ & $7.5 \pm 0.23^{\mathrm{cd}}$ & $4.6 \pm 0.85^{\mathrm{d}}$ & $198 \pm 38.35^{\text {cd }}$ & $23.5 \pm 4.22^{\mathrm{dg}}$ & $11.8 \pm 0.43^{*}$ & $7.6 \pm 0.35^{*}$ & $3.5 \pm 0.42^{\mathrm{f} *}$ & $187 \pm 25.19^{\mathrm{fg}}$ & $25.8 \pm 2.46^{\mathrm{g}}$ \\
\hline Oncorhynchus mykiss ${ }^{\mathrm{f}}$ & $15.1 \pm 0.45^{\mathrm{ab}}$ & $10.3 \pm 0.39$ & $7.0 \pm 1.56^{\mathrm{g}}$ & $578 \pm 126.51$ & $22.5 \pm 7.3^{\mathrm{g}}$ & $15.0 \pm 0.39$ & $9.7 \pm 0.37 *$ & $4.7 \pm 0.9 *$ & $352 \pm 69.39$ & $27.2 \pm 3.46$ \\
\hline Acipenser oxyrinchus ${ }^{\mathrm{g}}$ & $15.7 \pm 0.99^{\mathrm{ab}}$ & $11.3 \pm 0.75^{\mathrm{ae}}$ & $5.0 \pm 1.55$ & $455 \pm 137.49^{\mathrm{ac}}$ & $30.1 \pm 5.05$ & $16.0 \pm 1.48^{\mathrm{ac} *}$ & $11.0 \pm 0.73$ & $3.4 \pm 0.57^{\mathrm{cf}}$ & $302 \pm 106.69^{\mathrm{abc}}$ & $31.5 \pm 5.47^{\mathrm{abc}}$ \\
\hline
\end{tabular}


Riera et al. (1993), Lusková (1997, 1998), GuiJarro et al. (2003) the decrease in water temperature in autumn is usually accompanied by an increase in HB concentration. Apart from the season, HB concentration is influenced by the current energy needs of the organism, as well as, for example, prolonged hypoxia (NikinMaA 2002). Mean cellular hemoglobin concentration (MCHC) is constant for analyzed animals and does not depend on the season and the biology of the species (Table 2). Very low changeability of this index in all vertebrate was noticed already by WINTROBE in 1934 and it was confirmed in later works (Kostelecka-Myrcha 1973, 1997, 2002, Filho et al. 1992, Lusková 1997, Snyder and SHEAfor 1999). The constancy of mean cellular hemoglobin concentration proves that hemoglobin uses available space to the fullest extent (KosteleckaMyrcha 1973, Snyder and Sheafor 1999).

External environmental conditions as well as energy needs of a given organism exert a significant influence both on the hemoglobin concentration and the size and number of erythrocytes which determine the total surface area of these cells. Interestingly, our results clearly confirmed that despite observed diversity of those values, the $\mathrm{Hb} / \mathrm{TSAE}$ ratio remained constant independently of the season of the year and the biology of each species (Table 1). The amount of hemoglobin per erythrocyte surface unit (HB/TSAE) determines the efficiency of the saturation of hemoglobin with oxygen and therefore its maximum use in the transport of this gas (Kostelecka-Myrcha 1997, 2002). It is considered then that the HB/TSAE ratio exemplifies one of the most important hematological indices for indirectly describing metabolic properties of organisms (KosteleCKAMyrcha 2002). The amount of oxygen carried by erythrocytes in a unit of time depends on the blood flow rate (NIKINMAa 2001) while the efficiency of gas exchange is influenced by the flow rate of fresh water through the gills (WIESER 1991). In fish, however, the mechanism of cross-current gas exchange probably ensures sufficient contact time of erythrocytes with oxygen independently of the blood flow rate in the gills. As a consequence, fish are able to maintain a constant HB/TSAE ratio even when their ecological and physiological conditions differ. Interestingly, the average value of HB/TSAE ratio calculated for data given by Graham et al. (1985) concerns three species of deep-sea fish, living in considerably different environments and having different energy needs, was statistically similar to the values obtained for wild-lived but not for farmed i.e. rainbow trout and atlantic sturgeon, fresh-water fish presented in our study (see Appendix 2). Therefore, it may be supposed that in fish living in natural condition, despite the enormous diversity of red blood indices, the average amount of hemoglobin per erythrocyte surface unit is constant and does not depend on conditions of the external environment. The lack of appropriate data in literature makes it difficult to estimate the TSAE value for other species. However, the permanent hematocrit values in fish of various erythrocyte size and numbers (Boroń 1994, Cogswell et al. 2002, Ballarin et al. 2004, Perruzi et al. 2005), seem to confirm this hypothesis. The constancy of TSAE in specific physiological conditions or a particular season is probably caused by physiomorphological constraints (blood viscosity, capillary transit time, diameter of capillaries) (SNyder and Sheafor 1999). These constraints imposed on every 
organism necessitate a trade-off between the size and number of erythrocytes depending on the external environment, which leads to a great diversity of particular RBC indices.

An analogical situation occurs in birds, which, similarly to fish, have a constant HB/TSAE ratio independent of body mass, season of the year, or age of the individual (Kostelecka-Myrcha 1997, 2001). This constancy also stems from the mechanism of cross-current gas exchange in birds' tubular lungs, which ensures unchanging conditions of hemoglobin saturation with oxygen in this class of animals (Kostelecka-Myrcha 1997). Conversely, mammals, which are characterized by limited contact time of oxygen in their lungs, concentration of haemoglobin does not depend on the body mass while the number of erythrocytes is significantly lower among larger mammals (KosteleCKA-MYrCHA 2002). As a result, TSAE values are significantly higher among smaller species, while the HB/TSAE ratio is significantly greater (KostelECKA-MYrCHA 2002). The greater total surface area of red blood cells per unit volume of blood in small mammals probably allows for full saturation of haemoglobin by oxygen, even if the period of contact between erythrocytes and air in the lungs is shorter than in their larger counterparts. (Kostelecka-Myrcha 2002).

In summary, the presented results show that, notwithstanding considerable seasonable variability to the haematological parameters under consideration, the proportionality to the inferred changes is such as to ensure that a constant value for the HB/TSAE ratio is maintained in different species. This constancy of the ratio attests to haemoglobin saturation in the gills most likely taking place under constant conditions, notwithstanding the marked environmental changes from season to season. As in the case of birds, this constancy can be presumed to assure a mechanism for counter-current gaseous exchange providing a contact time between erythrocytes and oxygen that is of adequate length. The continued effectiveness of gaseous exchange may be further supported through regulation of the flow of oxygenated water through the gills (WIESER 1991). However, our study clearly shows that farmed species, in spite of the constancy HB/TSAE ratio between analyzed seasons, can differ with respect to its values in comparison to other - wild-live fish, as a result of probably different physiological adaptations. Thus, to resolve the general patterns of respiratory function of blood in fish just as in the case of birds and mammals, consecutive studies are needed.

\section{Acknowledgements}

We are greatly indebted to A. Roszkowska and J. Chołostiakow-Gromek for their skilful assistance in field work and blood sampling. We also thank an anonymous reviewer for thoughtful comments. 


\section{PRAWIDŁOWOŚCI ZMIAN WSKAŹNIKÓW CZERWONOKRWINKOWYCH CHARAKTERYZUJĄCYCH ODDECHOWĄ FUNKCJĘ KRWI RYB}

\section{STRESZCZENIE}

Słowa kluczowe: krew, pojemność tlenowa, parametry hematologiczne, sezonowość, ryby

U kręgowców występuje olbrzymie zróżnicowanie wartości wskaźników czerwonokrwinkowych, warunkujących sprawność transportu tlenu. U ryb, najprawdopodobniej ze względu na dużą zmienność środowiska wodnego, zróżnicowanie to jest szczególnie duże, co utrudnia znalezienie i zrozumienie ogólniejszych prawidłowości. Za miarę określającą zdolność jednostki objętości krwi do transportu tlenu przyjęto u ssaków iloraz hemoglobiny (HB) i sumarycznej powierzchni erytrocytów (TSAE). Stwierdzono również, że zarówno u ssaków, jak i u ptaków ilość hemoglobiny przypadająca na jednostkę powierzchni czerwonych krwinek (HB/TSAE) warunkuje maksymalne wykorzystanie tego barwnika oddechowego w transporcie tlenu, w różnych warunkach fizjologicznych i środowiskowych. W celu sprawdzenia czy prawidłowość ta obowiązuje u ryb, zmierzono wartości wskaźników czerwonokrwinkowych u siedmiu gatunków ryb słodkowodnych, znacznie różniących się biologią oraz masą ciała w dwóch sezonach roku. Pomimo dużej sezonowej zmienności składowych wyznaczających sumaryczną powierzchnię erytrocytów, wielkość TSAE zmieniała się proporcjonalnie do wzrostu stężenia HB. W konsekwencji stosunek HB/TSAE wyznaczający maksymalne wykorzystanie hemoglobiny $\mathrm{w}$ transporcie tlenu, był u każdego z gatunków stały pomiędzy analizowanymi sezonami. Stałość ta, podobnie jak u ptaków, wynika najprawdopodobniej z przeciwprądowej wymiany gazowej w skrzelach ryb.

\section{REFERENCES}

Ballarin L., Dall'Oro M., Bertotto D., Libertini A., Francescon A., Barbaro A. 2004: Haematological parameters in Umbrina cirrosa (Teleostei, Sciaenidae): a comparison between diploid and triploid specimens. Comp. Biochem. Physiol. 138A: $45-51$.

Boroń A. 1994: Use of erythrocyte measurement to detect natural triploids of spined loach Cobitis taenia (L.). Cytobios 78: 197-202.

Cogswell A.T., Benfey T.J., Sutterlin A.M. 2002: The hematology of diploid and triploid transgenetic Atlantic salmon (Salmo salar). Fish Physiol. Biochem. 24: $271-277$.

Cooper A., Taylor E.W., Wang T. 2001: Volume regulation by red blood cells from brown trout. J. Fish Biol. 59: 1098-1103.

Filho D.W., Eble G.J., Kassner G., Caprario F.X., Dafre A.L., Ohira M. 1992: Comparative hematology in marine fish. Comp. Biochem. Physiol. 102A: 311-321.

Graham M.S., Haedrich R.L., Fletcher, G.L. 1985: Hematology of three deep-sea fishes: A reflection of low metabolic rates. Comp. Biochem. Physiol. 80A: $79-84$.

GREgORY T.R. 2001: The bigger the c-value, the larger the cell: genome size and red blood cell size in vertebrates. Blood Cells Mole. Dis. 27(5): 830-843. 
Guijarro A.I., Lopez-Patino M.A., Pinillos M.L., Isorna E., De Pedro N., AlonsoGomez A.L., Alonso-Bedate M., Delgado M.J. 2003: Seasonal changes in haematology and metabolic resources in the tench. J. Fish Biol. 62: 803-815.

Hardie D.C., Hebert P.D.N. 2003: The nucleotypic effects of cellular DNA content in cartilaginous and ray-finned fishes. Genome 46: 683-706.

Hardie D.C., Hebert P.D.N. 2004: Genome-size evolution in fishes. Can. J. Fish Aquat. Sci. 61: 1636-1646.

Härdig J., Höglund, L.B. 1984: Seasonal variation in blood components of reared Baltic salmon, Salmo salar L. J. Fish Biol. 24: 565-579.

Homątowska A., Wojtaszek J., Adamowicz A. 2002: Haematological indices and circulating blood picture in the Sunbleak, Leucaspius delineates (Heckel, 1843). Zoologica Poloniae 47: 57-68.

Kostelecka-Myrcha A. 1973: Regularities of variations of the haematological values characterizing the respiratory function of blood in mammals. A. Theriol. 18(1): $1-56$.

Kostelecka-Myrcha A. 1997: The ratio of amount of haemoglobin to total surface area of erythrocytes in birds in relation to body mass, age of nestling, and season of the year. Physiol. Zool. 70: 278-282.

Kostelecka-Myrcha A., Cholostiakow-Gromek J. 2001: Body mass dependence of the haemoglobin content to surface area ratio of avian erythrocytes. A. Ornithol. 36: $123-128$.

Kostelecka-Myrcha A. 2002: The ratio of amount of haemoglobin to total surface area of erythrocytes in mammals. A. Theriol. 47(1): 209-220.

LAY P. A., BALDWIN J. 1999: What determines the size of teleost erythrocytes? Correlations with oxygen transport and nuclear volume. Fish Physiol. Biochem. 20: 31-35.

Lusková V. 1997: Annual cycles and normal values of hematological parameters in fishes. A. Scien. Nat. Brno 31: 1-70.

Lusková V. 1998: Factors affecting haematological indices in free-living fish populations. A. Vet. Brno 67: 249-255.

Maciak S., Janko K., Kotusz J., Choleva L., Boroń A., Juchno D., Kujawa R., KozŁowski J., Konarzewski M. 2011: Standard Metabolic Rate (SMR) is inversely related to erythrocyte and genome size in allopolyploid fish of the Cobitis taenia hybrid complex. Funct. Ecol. 25: 1072-1078.

Nespolo R.F. Rosenmann M. 2002: Intraspecific allometry of haematological parameters in Basilichthys australis. J. Fish Biol. 60: 1358-1362.

Nikinmaa M., Salama 1998: Oxygen transport in fish. In Fish Physiology, Vol. 17 (Perry S. \& Tufts B., eds), pp. 141-183. New York: Academic Press.

NikinmaA M. 2002: Oxygen-dependent cellular functions - why fishes and their aquatic environment are a prime choice of study. Comp. Biochem. Physiol. 133A: $1-16$.

Perruzi S., Varsamos S., Chatain B., Fauvel C., Menu B., Falguičre J., Sévčre A., Flik G. 2005: Haematological and physiological characteristics of diploid and triploid sea bass Dicentrarchus labrax L. Aquaculture 244: 359-367.

Promislow D.E.L. 1991: The evolution of mammalian blood parameters: patterns and their interpretation. Physiol. Zool. 64: 393-431.

Putnam R.W., Freel R.W. 1978: Hematological parameters of five species of marine fishes. Comp. Biochem. Physiol. 61A, 585-588. 
Riera M., Prats M.T., Palacios L., Pesquero J., Planas J. 1993: Seasonal adaptations in oxygen transport in brown trout Salmo trutta fario. Comp. Biochem. Physiol. 106A: 695-700.

Snyder G.K., Sheafor B.A. 1999: Red blood cells: Centerpiece in the evolution of the vertebrate circulatory system. Am. Zool. 39: 189-198.

Wieser W. 1991: Physiological energetics and ecophysiology. In Cyprinid fishes: systematics, biology and exploitation (Winfield I.J., Nelson J.S., eds.), Fish and fisheries Series 3, pp. 426-455. London: Chapman \& Hall.

Wintrobe M.M. 1934: Variations in the size and hemoglobin content of erythrocytes in the blood of various vertebrates. Folia Heamatologica 51: 32-49.

Wintrobe M.M. 1967: Clinical Hematology. Philadelphia. Lea and Febiger.

Ytrestøyl T., Finstad B., McKinley R.S. 2001: Swimming performance and blood chemistry in Atlantic salmon spawners exposed to acid river water with elevated aluminium concentrations. J. Fish Biol. 58: 1025-1038. 


\section{Appendix 1.}

The area of an individual erythrocyte is best described by that of a triaxial ellipsoid in which three cell dimensions are analysed simultaneously. Accepting that $a=\frac{L C}{2} ; b=\frac{W C}{2} ; c=\frac{T C}{2}$ and $T C=\frac{6 M C V}{\Pi L C * W C}$ then $\frac{x^{2}}{a^{2}}+\frac{y^{2}}{b^{2}}+\frac{z^{2}}{c^{2}}=1$ where $(\mathrm{a}>\mathrm{b}>\mathrm{c})$ and the surface area $S=\left(2 \Pi c^{2}+\frac{2 \Pi b}{\sqrt{a^{2}-c^{2}}} c^{2} * F(k, \varphi)+\left(a^{2}-c^{2}\right) * E(k, \varphi)\right)$, $F(k, \varphi)$ and $E(k, \varphi)$ are respectively elliptic integrals of types I and II, whose values can be read from the tables, where $\varphi=\arcsin \frac{\sqrt{a^{2}-c^{2}}}{a}$ and $k=\frac{a \sqrt{b^{2}-c^{2}}}{b \sqrt{a^{2}-c^{2}}}$.

As the total surface of erythrocytes is the product of the number of erythrocytes per $\mathrm{mm}^{3}$ of blood and the surface area of a single blood cell (S):

$T S A E=R B C *\left(2 \Pi c^{2}+\frac{2 \Pi b}{\sqrt{a^{2}-c^{2}}} c^{2} * F(k, \varphi)+\left(a^{2}-c^{2}\right) * E(k, \varphi)\right)$.

\section{Appendix 2.}

Data recount given by GRAHAM et al. (1985) for three species of deep-sea fish (Antimora rostrata (Moridae), Lycodes esmarkii (Zoarcidae), Macrurus berglax (Macrouridae)) with formulas from Appendix 1, reveled similar values of total erythrocytes surface area in these animals (respectively: $193.84 \mathrm{~mm}^{2} \mathrm{~mm}^{-3}$ for $A$. rostrata; $181.74 \mathrm{~mm}^{2} \mathrm{~mm}^{-3}$ for L. esmarkii and $229.66 \mathrm{~mm}^{2} \mathrm{~mm}^{-3}$ for M. berglax). Minimal differences in TSAE values between various species correspond with differences in hemoglobin concentration in these animals. As a result $\mathrm{Hb} / \mathrm{TSAE}$ ratio was similar in those fish (respectively: $0.026 ; 0.024 ; 0.024)$ and was statistically not different from the values obtained for wild-lived species of freshwater fish (ANCOVA; $\mathrm{F}=1.77 ; \mathrm{p}=0.072$ ). 